\section{VIAJE PÓSTUMO/ VIATGE PÒSTUM}

\author{
Cruchaga, A. (2014)
}

\section{El Salvador: Imprenta Rilcadone. José Siles González}

CEU Facultad Ciencias de la Salud. Universidad de Alicante Cómo citar este artículo (reseña) en edición digital: Siles González, J. (2015). Viaje Póstumo/ Viatge pòstum (Reseña). Cultura de los

Cuidados (Edición digital) 19, 41.

Disponible en:

http://dx.doi.org/10.14198/cuid.2015.41.21> Correspondencia: (remitirse al correo electrónico)

Correo electrónico: jose.siles@ua.es.

Recibido: 10/01/2014/ Aceptado: 22/01/2015

Se nos presenta la edición en castellano y valenciano de una obra del poeta salvadoreño André Cruchaga cuya traducción ha estado a cargo de Pere Bessó filólogo y catedrático de lengua y literatura española. André Cruchaga es profesor de humanidades y como núcleo enriquecedor de su actividad docente, ha desarrollado una importante y extensa obra poética que ha sido galardonada con diferentes premios literarios y ha traducida a diferentes idiomas: francés, rumano, holandés, vasco, valenciano, etc. Entre sus obras destacan: Alegoría de la palabra (1992), Visión de la muerte (1994), Enigma del tiempo (1996), Roja Vigilia (1997), Rumor de pájaros (2002), Pie en tierra (2007), Caminos Cerrados (2009), Viajar de la ceniza (2010), Cuaderno de ceniza (2013), Balcón del vértigo (2014), Post scriptum (2014), etc. Además ha publicado sus poemas en las revistar literarias más prestigiosas de España y América Latina.

André Cruchaga es un poeta de gran altura que puede provocar cierta hipoxia y desvanecimiento en los lectores desprevenidos que no están acostumbrados a caminar por senderos contiguos a los grandes desfiladeros donde habita, en la profundidad abisal, la palabra con mayúsculas. La palabra como sentimiento que es imagen y

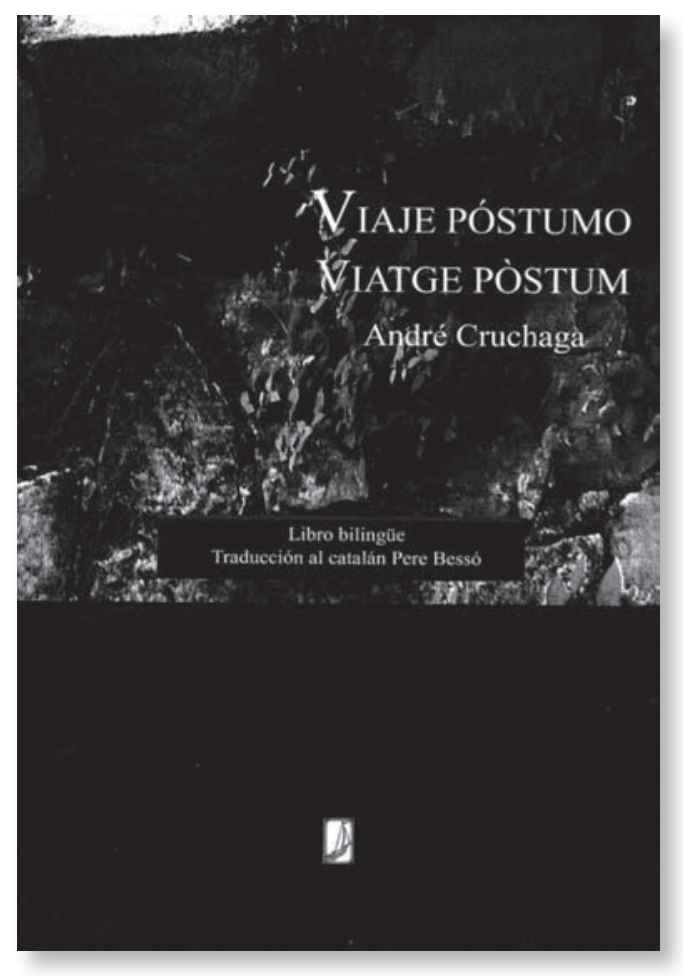

que se funde con aromas telúricos de tiempos imperecederos: la metáfora al servicio de una creatividad combativa sostenedora de esa clase de dignidad se sustenta en la observación de la realidad; un entorno envolvente cuyo caos es tan subterráneo y trascendente que se intangibiliza en la superficie insustancial y rutinaria de una vida cotidiana fabricada para convertirnos en inconscientes. Sí, el poeta salvadoreño, con su verso inflamado que todo lo ilumina, nos despierta y avisa del creciente auge del pensamiento automático que acaba transformando nuestra existencia en un devenir superfluo entre horarios lineales de comidas, cenas, idas y venidas al trabajo y largas sentadas frente al sedante televisor.

El poeta Cruchaga emplea herramientas como el simbolismo y la metáfora para rescatar trozos de conciencia faenando poéticamente en los caladeros de un ultra-realismo cargado de dolor e incertidumbre: paso incontrolable del tiempo, envejecimiento, muerte, despropósitos 
del ser humano que acaba transformando lo más hermoso en pura miseria..., inexistencia; pero mediante su poesía profundiza en los temas centrales de la vida como la misma muerte (asalariada por la vida para sus propios fines..., especialmente el postrero y definitivo):.Así en "Muerte" nos avisa de que es la medida de todas las cosas:

"Muero cada día cuando resbalo en la cuerda floja del tiempo, este aliento carece ya de sombreros cae la respiración hasta los tobillos, ¿qué me queda después de lamer los excrementos? (Morir antes que mueran las palabras es la mejor solución). Morir como se embriaga el tejado... “ (Cruchaga, 2014: 192)

Cruchaga es un poeta que no hace concesiones a la galería y reinterpreta la realidad desnuda del discurrir de la vida como metáfora de navegación existencial donde todo está en conexión:

\section{Navegación}

"A través del barro, las manos tallan las distancias: esos pasos lentos del desvelo, las sombras diurnas del relámpago, la piedra de la fatiga donde deslumbran tantas instantáneas (...)" (Cruchaga, 2014: 164).

También se detiene el poeta en las secuelas del paso del tiempo y la manifestación de un inevitable arte, El olvido:

"Sueño ya el olvido y las extrañezas en vísperas de relojes caducos. El horizonte es irreparable en las postrimerías de la edad (también los mostradores huesudos de las talabarterías, los disfraces cumplidos de los funerales sobre el mundo infinito del desquicio)(...)"

Es Cruchaga un poeta atento a los sentimientos que le provocan sus capacidades perceptivas y lo refleja magistralmente en "Olfato":

"Cuando el árbol de repente abre sus dominios, el olfato implora al pájaro etéreo del cierzo, -volve- ré a trepar al vendaval de la noche, a su dosis de trementina, a su embriaguez de escritura muerta".

En el poema que da título al poemario "Viaje póstumo", el poeta se sitúa en una posición álgida de anticipada nostalgia para despedirse sin desistir de estar y dejando constancia de lo que pensará y hablará cuando ya no pueda pensar ni hablar:

"Que la luz hunda su imagen en mi lápida. Animada y visible al mismo tiempo. Más allá de lo anónimo y el olvido, soy ciudadano de este país. Pon una rosa sin aldabas sobre mi cruz, un pétalo tan solo hacia el horizonte como vos una calle que desafíe al tiempo (...)"

Por todo esto y mucho más presente en su dilatada obra, André Cruchaga es un poeta de gran altura que puede llegar a provocar cierto vértigo en los lectores desprevenidos que tal vez estén más acostumbrados a la poesía de salón donde emerge de forma rebuscada y artificiosa lo amable, feliz y bienaventurado que es ese bicho bipedestador que es el hombre. No, no están acostumbrados a caminar por senderos contiguos a los grandes desfiladeros donde habita, en la profundidad abisal, la palabra con mayúsculas..., la única capaz de aprehender y transmitir cuestiones tan esenciales como la auténtica y contradictoria realidad del ser humano. 